\title{
Phytoprotection
}

\section{Principles of insecticide resistance management}

\section{G.P. Georghiou}

Volume 75, numéro 4, 1994

Herbicide Resistance Workshop - Edmonton, Alberta - 9 and 10 december 1993

Atelier sur la résistance aux herbicides - Edmonton (Alberta) - 9 et 10 décembre 1993

URI : https://id.erudit.org/iderudit/706071ar

DOI : https://doi.org/10.7202/706071ar

Aller au sommaire du numéro

\section{Éditeur(s)}

Société de protection des plantes du Québec (SPPQ)l

\section{ISSN}

0031-9511 (imprimé)

1710-1603 (numérique)

Découvrir la revue

Citer cet article

Georghiou, G. (1994). Principles of insecticide resistance management. Phytoprotection, 75(4), 51-59. https://doi.org/10.7202/706071ar

\section{Résumé de l'article}

La demande pour des stratégies efficaces de gestion de la résistance se fait de plus en plus pressante, au fur et à mesure que le nombre d'espèces résistantes aux insecticides augmente mondialement alors que les ressources insecticides diminuent. Les perspectives de développement de telles stratégies sont accrues par les développements récents en biochimie, en génétique moléculaire, en écologie, en dynamique, en dépistage et dans d'autres aspects importants de la résistance. Les approches généralement reconnues pour la gestion de la résistance sont regroupées en trois catégories principales: une pression de sélection faible, complétée par une composante élevée de mesures non-chimiques (gestion par modération); l'élimination de l'avantage sélectif des individus résistants en augmentant l'absorption des insecticides par l'utilisation d'attractifs, ou en supprimant les enzymes de detoxication par l'utilisation de synergistes (gestion par saturation); l'application d'une sélection multi-directionnelle au moyen de mélanges ou de rotations d'insecticides non-apparentés ou par l'utilisation d'insecticides à plusieurs sites d'action (gestion par attaque multiple). Ces approches ne sont pas mutuellement exclusives et des éléments de chacune peuvent être utilisés pour la formulation d'un programme saisonnier de gestion. La stratégie choisie doit être basée sur une connaissance approfondie des effets sur la résistance des insecticides envisagés, et de la biologie et de l'écologie des espèces concernées, et elle doit utiliser toutes les méthodes de lutte non-chimiques disponibles.
Ce document est protégé par la loi sur le droit d'auteur. L'utilisation des services d'Érudit (y compris la reproduction) est assujettie à sa politique d'utilisation que vous pouvez consulter en ligne.

https://apropos.erudit.org/fr/usagers/politique-dutilisation/ 


\title{
Principles of insecticide resistance management
}

\author{
George P. Georghiou'
}

Received 1994-01-17; accepted 1994-07-27

The need for effective strategies in resistance management is becoming more pressing as the number of insecticide-resistant species continues to increase worldwide while insecticide resources are diminishing. Prospects for development of such strategies are enhanced by recent advances in knowledge on the biochemistry, molecular genetics, ecology, dynamics, monitoring, and other important aspects of resistance. The generally recognized approaches to resistance management are grouped under three principal categories: first, low selection pressure, supplemented by a strong component of non-chemical measures (management by moderation); second, elimination of the selective advantage of resistant individuals by increasing insecticide uptake through the use of attractants, or by suppressing of detoxication enzymes through the use of synergists (management by saturation); and third, application of multi-directional selection by means of mixtures or rotations of unrelated insecticides or by use of chemicals with multi-site action (management by multiple attack). These approaches are not mutually exclusive and elements from each can be used to formulate a season-long management program. The strategy chosen must be based on a thorough knowledge of the resistance implications of the candidate insecticides and of the biology and ecology of the species concerned, and must make use of all available non-chemical control measures.

Georghiou, G.P. 1994. Principes de gestion de la résistance aux insecticides. PHYTOPROTECTION 75 (Suppl.): 51-59.

La demande pour des stratégies efficaces de gestion de la résistance se fait de plus en plus pressante, au fur et à mesure que le nombre d'espèces résistantes aux insecticides augmente mondialement alors que les ressources insecticides diminuent. Les perspectives de développement de telles stratégies sont accrues par les développements récents en biochimie, en génétique moléculaire, en écologie, en dynamique, en dépistage et dans d'autres aspects importants de la résistance. Les approches généralement reconnues pour la gestion de la résistance sont regroupées en trois catégories principales: une pression de sélection faible, complétée par une composante élevée de mesures non-chimiques (gestion par modération); l'élimination de l'avantage sélectif des individus résistants en augmentant l'absorption des insecticides par I'utilisation d'attractifs, ou en supprimant les enzymes de détoxication par l'utilisation de synergistes (gestion par saturation); I'application d'une sélection multi-directionnelle au moyen de mélanges ou de rotations d'insecticides non-apparentés ou par l'utilisation

1. Department of Entomology, University of California, Riverside, California, U.S.A. 92507 
d'insecticides à plusieurs sites d'action (gestion par attaque multiple). Ces approches ne sont pas mutuellement exclusives et des éléments de chacune peuvent être utilisés pour la formulation d'un programme saisonnier de gestion. La stratégie choisie doit être basée sur une connaissance approfondie des effets sur la résistance des insecticides envisagés, et de la biologie et de l'écologie des espèces concernées, et elle doit utiliser toutes les méthodes de lutte non-chimiques disponibles.

\section{Nomenclature of chemical names cited in the text:}

Apholate: N-[4-[[(2,4-diamino-6-pteridinyl)methyl]methylamino]benzoyl]glutamic acid; avermectin: butyl-21,24-dihydroxy-5',11,13,22-tetramethyl-2-oxo-3,7,19-trioxatetracyclo; DDT: 1,1,1-trichloro-2,2-bis(4-chlorophenyl)ethane; diflubenzuron: 1-(4-chlorophenyl)-3-12,6difluorobenzoyl)urea; methoprene: isopropyl (E,E)-11-methoxy-3,7,11-trimethyl-2,4-dodecadienoate; permethrin: 3-phenoxybenzyl(1RS, 3RS; 1RS, 3SR)-3-(2,2-dichlorovinyl-2,2-dimethylcyclopropanecarboxylate; piperonyl butoxide: 2-(2-butoethoxy)ethyl 6-propylpiperonyl ether.

\section{INTRODUCTION}

It has been almost 50 years since the discoverer of DDT won the Nobel prize in chemistry. Unfortunately, that discovery, and many subsequent discoveries of insecticides, were followed closely by the development of resistance. According to a data bank that we maintain for the Food and Agriculture Organization of the United Nations (FAO), the number of species of insects and mites worldwide that have developed strains resistant to one or more chemicals has increased to at least 504 (Georghiou 1990; Georghiou and Lagunes-Tejeda 1991) and continues to rise.

Many of the major pest species are already resistant to members of each of the principal classes of insecticides. Furthermore, laboratory selections, mainly on mosquitoes (Anopheles or Culex spp. [Diptera: Culicidae]) and house flies (Musca domestica L. [Diptera: Muscidae]), have revealed insects' ability to develop resistance to many other control products of disparate modes of action. Included among these are juvenile hormone mimics, e.g. methoprene, chitin synthesis inhibitors, e.g. diflubenzuron, GABA ( $\gamma$-aminobutyric acid) inhibitors, e.g. avermectin, bacterial toxins (Bacillus thuringiensis, B. sphaericus) and chemosterilants, e.g. apholate (Georghiou 1986).
With cases of resistance on the rise and insecticide resources declining, it has become apparent that chemical pest control, as practiced today, may no longer be sustainable without the availability of specific strategies and tactics for the prevention or management of resistance. Before entering into a discussion of resistance management, it would be useful to provide some background on the mechanisms and dynamics of resistance.

\section{PROPENSITY FOR RESISTANCE}

It is well established that resistance does not evolve at the same rate in every species or population. Resistance may develop rapidly in some populations and slowly in others. Selections in the laboratory under seemingly similar conditions, mainly on house flies and mosquitoes, have shown varying propensities for resistance to different insecticides. Resistance evolved most rapidly and to higher levels toward the pyrethroid permethrin and most slowly toward the toxin complex of Bacillus thuringiensis subsp. israelensis (BTI) (Georghiou 1990).

Since under common usage practices, resistance to a selecting agent may be expected to rise to high levels, resistance management strategies are now being sought which would permit 
longer, perhaps indefinite, effective use of new compounds. We define resistance management as the containment of the frequency of resistance genes below an acceptable limit by means of strategic choice of insecticide, dosage, mode of application, and frequency of use.

The knowledge that is required for devising resistance management strategies is of two types: one pertains to the mechanisms of resistance in individual insects, the other to the dynamics of resistance in populations.

\section{MECHANISMS OF RESISTANCE}

The mechanisms of resistance are shown diagrammatically in Figure 1 (Georghiou 1990). The circle represents a cross section through the insect: the left part represents a susceptible insect, the right a resistant insect. Normally, an insecticide penetrates rapidly through the integument, reaching the site of action. The site may be a vital enzyme, nerve tissue, or receptor pro-

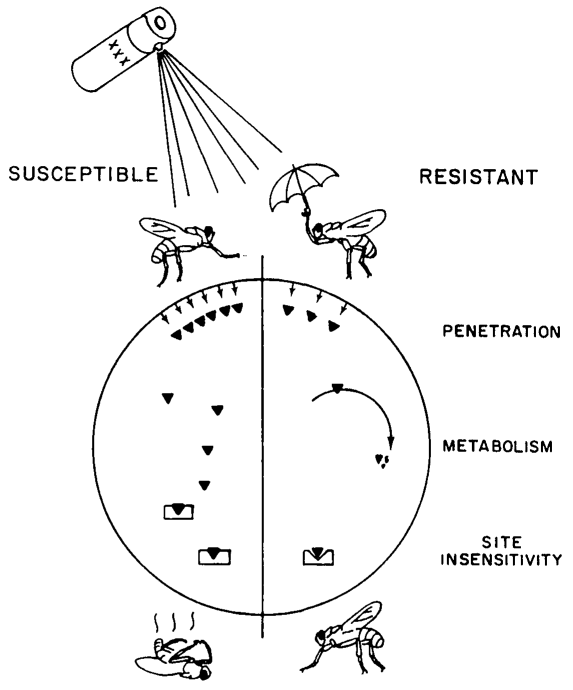

Figure 1. Diagrammatic representation of three principal types of resistance mechanisms in cross section through susceptible (left) and resistant (right) insects. (Adapted from Georghiou 1987). tein. Insecticide molecules bind to the site, and when they have attained threshold concentrations, they cause the insect's death. Resistance may be selected at each step of this pathway: the integument may be selected for lower permeability, thus reducing the rate of entry of the insecticide; new or more abundant metabolic enzymes may be selected, which break down the insecticide more efficiently; and altered target sites may be selected on which the insecticide no longer binds. Of these three types of mechanisms, metabolism and insensitivity at the site of action are the most important (Table 1). A reduction in the rate of cuticular penetration aids both types of mechanisms in a synergistic way.

The mechanisms of resistance have been discussed in several recent publications (Cuany et al. 1993; Ketterman et al. 1992, 1993; Mullin and Scott 1992; Otto and Weber 1992; Roush and Tabashnik 1990; Thompson et al. 1993). Several important advances which directly aid research in resistance management have been achieved during the past few years. For example, progress has been made in the elucidation of the molecular genetics of resistance. Genes encoding resistance mechanisms have been cloned, revealing whether resistance is due to one or more nucleotide substitutions (Amichot et al. 1992; Feyereisen et al. 1989; ffrench-Constant et al. 1993; Taylor et al. 1993; Williamson et al. 1993), to gene amplification (Devonshire and Field 1991; Ferrari and Georghiou 1990, 1991; Mouchès et al. 1986, 1990; Oei et al. 1992; Raymond et al. 1989), or to other means. The biochemical mechanisms of resistance to new insecticides, such as pyrethroids (Mullin and Scott 1992; Otto and Weber 1992; Soderlund and Bloomquist 1990), Bacillus thuringiensis (Ferré et al. 1991; Gould et al. 1992; Van Rie et al. 1990) and Bacillus sphaericus (Nielsen-Leroux and Charles 1993) have been determined. Practical tests for detection of specific mechanisms of resistance in individual insects have been developed. These include filter paper tests for esterases (Pasteur and Georghiou 1989) and acetylcholinesterase (AChE) (Dary et al. 1991), microti- 
Table 1. Importance of different mechanisms of resistance to five insecticide classes

\begin{tabular}{|c|c|c|c|c|c|}
\hline \multirow[b]{2}{*}{ Mechanisms } & \multicolumn{5}{|c|}{ Insecticide classes $^{\mathrm{a}}$} \\
\hline & DDT & OP & Carb. & Pyr. & BT \\
\hline \multicolumn{6}{|l|}{ Metabolic } \\
\hline Esterases & $\cdot$ & $++t^{b}$ & + & ++ & - \\
\hline Monooxygenases & ++ & ++ & +++ & ++ & - \\
\hline Dehydrochlorinases & +++ & $\cdot$ & • & $\cdot$ & - \\
\hline Glutathione transferases & $\cdot$ & ++ & - & - & - \\
\hline \multicolumn{6}{|l|}{ Non-metabolic } \\
\hline Altered acetylcholinesterase & $\cdot$ & +++ & +++ & $\cdot$ & - \\
\hline Altered sodium channel & +++ & • & $\cdot$ & +++ & $\cdot$ \\
\hline Altered toxin receptor & $\cdot$ & - & - & $\cdot$ & +++ \\
\hline Reduced penetration & + & + & + & + & • \\
\hline
\end{tabular}

a $\mathrm{OP}=$ organophosphate; Carb. = carbamate; $\mathrm{Pyr}$ = pyrethroid; $\mathrm{BT}=$ Bacillus thuringiensis.

b $+++=$ very important $;+\boldsymbol{+ +}=$ important; $+=$ minor; $\cdot=$ no effect

Table 2. Factors influencing the rate of selection of resistance

\begin{tabular}{|c|c|c|c|}
\hline Factors & \multicolumn{2}{|c|}{ Correlation to resistance ${ }^{\mathrm{a}}$} & \\
\hline \multicolumn{4}{|l|}{ Genetic } \\
\hline Number of $\mathrm{R}^{\mathrm{b}}$ genes & + & - & \\
\hline Frequency of $R$ gene & + & - & \\
\hline Dominance of $\mathrm{R}$ gene & + & - & \\
\hline Penetrance, expressivity of $R$ gene & + & - & \\
\hline Past selection by related chemicals & + & - & \\
\hline Integration of $\mathrm{R}$ with fitness & + & • & \\
\hline \multicolumn{4}{|l|}{ Biological/Ecological } \\
\hline Generation turnover & + & - & \\
\hline Offspring per generation & + & • & \\
\hline Polygamy & + & - & \\
\hline Parthenogenesis & • & - & \\
\hline Monophagy & + & - & \\
\hline Occurrence of "refugia" & - & - & \\
\hline Isolation & + & - & . \\
\hline Mobility, dispersal & - & - & \\
\hline \multicolumn{4}{|l|}{ Operational } \\
\hline Chemistry of pesticide & + & - & \\
\hline Persistence of residues & + & - & \\
\hline Application threshold & $\cdot$ & - & \\
\hline Selection threshold & + & - & \\
\hline Life stage controlled & + & - & \\
\hline Incomplete coverage & - & - & \\
\hline Infrequent or alternating selection & $\cdot$ & - & \\
\hline
\end{tabular}


ter plate tests for esterases (Dary et al. 1990), AChE (Brogdon 1988; Hemingway et al. 1986; Raymond et al. 1985), monooxygenases (MFO), glutathione transferases (GSH), and others (Georghiou 1990).

\section{DYNAMICS OF RESISTANCE}

The availability of a large number of case histories of resistance offers a better perspective for understanding the factors that influence its evolution. We have classified these factors into three categories: genetic, biological and operational (Table 2) (Georghiou and Taylor 1976, 1986). Through modeling, we have quantified the influence of individual factors and have shown that some are positively correlated with the growth of resistance (i.e. gene dominance, population isolation, insecticide persistence, etc.), while others are negatively correlated (immigration, refugia) (Georghiou and Taylor 1977a, 1977b). If the relative influence of each factor could be expressed quantitatively, a comprehensive model might be constructed that measures the risk for resistance in a given situation. That risk can then be reduced through appropriate modification of one or more of the operational factors, since these are under man's control.

\section{STRATEGIES FOR RESISTANCE MANAGEMENT}

The approaches to resistance management may be grouped under three headings: management by moderation, management by saturation and management by multiple attack (Table 3 ). Reviews of the extensive literature on resistance management strategies have been made by Curtis et al. (1993), Denholm and Rawland (1992), Ford et al. (1987), Forrester et al. (1993), Georghiou (1983, 1990), McGaughey and Whalon (1992), Tabashnik (1989) and others.

\section{Management by moderation}

Management by moderation recognizes that susceptibility genes are a valuable resource and it attempts to preserve them by limiting the chemical selection pressure that is applied. Measures in this category include lower insecticide rates, infrequent applications, non-persistent chemicals, and preservation of refugia. It is apparent that these measures are conservative, and in most cases, must be supplemented by non-chemical measures such as insect-resistant varieties, improved timing of planting and harvesting, encouragement of biological controls, etc. While management by moderation comes close to meeting environmental standards and is less destructive to biological controls, it may not be appealing where high value crops must be protected, vectors of human disease suppressed, or newly introduced pests eradicated. In these cases, the saturation or multiple attack concepts may be more appealing.

\section{Management by saturation}

The term "saturation" does not imply saturation of the environment with pesticides. It is intended to indicate saturation of the insect's defenses by means of on-target dosages that are high enough to overcome resistance. This approach has more merit during the early stages of selection when resistance genes are rare, existing mainly in the heterozygous state. Formulations that could deliver high dosages on-target include microencapsulation, or the use of attractants [as in medfly [Ceratitis capitata (Wied.)] [Diptera: Tephritidae] eradication sprays], or baited targets [as in tsetse fly (Glossina spp.) [Diptera: Glossinidae] control], causing insecticide uptake at rates that are lethal to heterozygotes.

Another means of suppressing the insect's defenses is the use of synergists. Piperonyl butoxide (PB) has been used for many years as a synergist of pyrethrins in household aerosol sprays, and more recently with pyrethroids in agricultural pest control (e.g. Helicoverpa armigera (Hübner) [Lepidoptera: Noctuidae], Leptinotarsa decemlineata (Say) [Coleoptera: Chrysomelidae]). By suppressing the insect's mixed function oxidase system, which is involved 
Table 3. Principles of management of resistance by moderation, saturation, and multiple attack

\begin{tabular}{lll}
\hline Concept & Approach & Means \\
\hline $\begin{array}{l}\text { Moderation } \\
\text { Susceptible genes are a }\end{array}$ & Low selection pressure & Low doses producing \\
valuable resource that must & & $<100 \%$ mortality of $\$ S^{a}$ \\
be conserved while & Higher pest population \\
achieving economic control. & thresholds for treatment \\
& Less frequent \\
& applications \\
& Localized applications \\
& Preservation of refugia \\
& Some generations \\
& untreated \\
& Chemicals of short \\
& environmental
\end{tabular}

\section{Saturation}

Removal of selective advantage of resistant phenotypes by saturation of defense mechanisms.

Multiple attack

Multi-directional, multi-site selection reduces degree of pressure by a single factor.
Rendering $R^{a}$ genes functionally recessive

Suppressing detoxication enzymes

Maintaining degree of selection by each component factor below levels leading to resistance
Higher doses on-target can render $\mathrm{R}$ genes functionally recessive, thus RS = SS.

Appropriate synergist can cancel out specific detoxication enzymes and remove selective advantage of $\mathrm{RS}^{\mathrm{a}}$ and $\mathrm{RR}^{\mathrm{a}}$.

Mixtures of chemicals Rotation of chemicals Chemicals with multisite action

${ }^{\text {a }} \mathrm{SS}=$ homozygous susceptible; $\mathrm{RS}$ = heterozygote; $\mathrm{RR}=$ homozygous resistant; $\mathrm{R}$ = resistant.

in the degradation of pyrethroids, $\mathrm{PB}$ effectively removes the selective advantage of this mechanism. The approach would not apply where alternative pathways of detoxication, [e.g. the pyrethroid resistance mechanism knockdown resistance $(k d r)]$, are also present (Ranasinghe and Georghiou 1979).

Each of these approaches could find application in specific situations. A strategy based on moderation would be appropriate in a forest environment. A saturation tactic might be feasible in a greenhouse, a grain elevator, in bait sprays, etc.

\section{Management by multiple attack}

The multiple attack strategy is based on the premise that control can be achieved through the action of several independently acting stresses, including insecticides, each exerting selection pressure that is below the level which could lead to resistance. This approach includes the application of chemicals in mixtures and rotations (Georghiou 1983, 1990; Roush and McKenzie 1987; Tabashnik 1989).

The strategy of using mixtures assumes that the mechanisms of resistance to each member chemical are different and that initially they exist at 
such low frequencies that they do not occur together in any single individual within a given population. Thus, insects that survive one of the chemicals in the mixture are killed by the other.

The strategy of using rotations is based on data which indicate that during the early stages of selection, (resistant individuals may possess lower biotic fitness) the cost of resistance, than susceptible individuals. This lower fitness causes a gradual decline in the frequency of resistant individuals when the selecting insecticide is withdrawn, or is replaced by a neutral insecticide that is not affected by cross-resistance.

The feasibility of using two insecticides in rotation, mixture, or sequentially for resistance management has been examined in several laboratories by means of cage experiments (Cilek and Knapp 1993; Curtis et al. 1993; Georghiou et al. 1983; McKenzie and Byford 1993). As expected, the use of different insecticides and different species of insects has led to divergent conclusions. It is obvious that the success of each approach will depend on many factors, including the proper choice of chemicals based on their mode of action, the potential mechanisms of resistance to them, the prior exposure of the target population to insecticidal selection pressure, and the presence of a significant fitness differential between resistant and susceptible individuals.

A large scale resistance management program has been in effect in eastern Australia since 1983, aimed at managing resistance to pyrethroids by restricting their use to a mid-season narrow window period of $42 \mathrm{~d}$ (35 d from the 1989-1990 season onward). As described by Forrester et al. (1993) in a comprehensive report, this strategy may have extended the use life of pyrethroids but has not prevented resistance from evolving, because of progressive contamination of refugia by resistant individuals and the absence of significant fitness differential between susceptible and resistant insects. Interestingly, the mechanism of pyrethroid resistance that has evolved is based on detoxication by MFO enzymes, instead of the more powerful $k d r$ mechanism. Subsequent introduction of the synergist PB with pyrethroids was found to suppress MFO detoxication, thus enabling continuation of pyrethroid use in moderation.

\section{CONCLUSION}

Despite the progress made in our understanding of the biochemistry of resistance and its dynamics in field populations, no single prescription can be offered that will forestall resistance under all situations. There are literally hundreds of different pest species that are under chemical control, and each species represents several distinct combinations of biological and ecological characteristics. Management by moderation should be the basic approach and should be supplemented to the maximum possible by integrated pest management measures. Recourse to the other strategies described here will be essential in many cases, especially where high value crops or vectors of human disease are involved. In such cases, the strategy chosen must be based on thorough knowledge of the resistance implications of the candidate insecticides and of the biology and ecology of the species concerned.

\section{REFERENCES}

Amichot, M., C. Castella, A. Cuany, J.B. Bergé, and D. Pauron. 1992. Target modification as a molecular mechanism of pyrethroid resistance in Drosophila melanogaster. Pestic. Biochem. Physiol. 44: 183-190.

Brogdon, W. 1988. Microassay of acetylcholinesterase activity in small portions of single mosquito homogenates. Comp. Biochem. Physiol. 90C: 145-150.

Cilek, J.E., and F.W. Knapp. 1993. Enhanced diazinon susceptibility in pyrethroidresistant horn flies (Diptera: Muscidae): Potential for insecticide resistance management. J. Econ. Entomol. 86: 13031307.

Cuany, A., J. Handani, J. Bergé, D. Fournier, M. Raymond, G.P. Georghiou, and N. Pasteur. 1993. Action of esterase B1 on chlorpyrifos in organophosphate-resistant Culex mosquitoes. Pestic. Biochem. Physiol. 45: 1-6. 
Curtis, C.F., N. Hill, and S.H. Kasim. 1993. Are there effective resistance management strategies for vectors of human disease? Biol. J. Linn. Soc. 48: 3-18.

Dary, O., G.P. Georghiou, E. Parsons, and N. Pasteur. 1990. Microplate adaptation of Gomori's assay for quantitative determination of general esterase activity in single insects. J. Econ. Entomol. 83: 21872192.

Dary, O., G.P. Georghiou, E. Parsons, and N. Pasteur. 1991. Dot-blot test for identification of insecticide-resistant acetylcholinesterase in single insects. J. Econ. Entomol. 84: 28-33.

Denholm, I., and M.W. Rowland. 1992. Tactics for managing pesticide resistance in arthropods: Theory and practice. Annu. Rev. Entomol. 37: 91-112.

Devonshire, A.L., and L.M. Field. 1991. Gene amplification and insecticide resistance. Annu. Rev. Entomol. 36: 1-23.

Ferrari, J.A., and G.P. Georghiou. 1990. Esterase B1 activity variation within and among insecticide-resistant, susceptible, and heterozygous strains of Culex quinquefasciatus (Diptera: Culicidae). J. Econ. Entomol. 83: 1704-1710.

Ferrari, J.A., and G.P. Georghiou. 1991. Quantitative genetic variation of esterase activity associated with a gene amplification in Culex quinquefasciatus. Heredity 66: 265-272.

Ferré, J., M.D. Real, J. Van Rie, S. Jansens, and M. Peferoen. 1991. Resistance to the Bacillus thuringiensis bioinsecticide in a field population of Plutella xylostella is due to a change in a midgut membrane receptor. Proc. Nat. Acad. Sci. USA 88: 5119-5123.

Feyereisen, R., J.E. Loener, D.E. Farnsworth, and D.W. Nebert. 1989. Isolation and sequence of cDNA encoding a cytochrome $P_{-450}$ from an insecticide-resis-tant strain of the house fly, Musca domestica. Proc. Nat. Acad. Sci. USA 86: 1465-1469.

ffrench-Constant, R.H., T.A. Rocheleau, J.C. Steichen, and A.E. Chambers. 1993. A point mutation in a Drosophila GABA receptor confers insecticide resistance. Nature (Lond.) 363: 449-451.

Ford, M.G., D.W. Holloman, B.P.S. Khambay, and R.M. Sawicki (eds). 1987. Combating resistance to xenobiotics. Ellis Horwood, Chichester, England. 320 pp.

Forrester, N.W., M. Cahill, L.J. Bird, and J.K. Layland. 1993. Management of pyrethroid and endosulfan resistance in Helicoverpa armigera (Lepidoptera: Noctuidae) in Australia. Bull. Entomol. Res., Suppl. 1, $132 \mathrm{pp}$.
Georghiou, G.P. 1983. Management of resistance in arthropods. Pages 769-792 in G.P. Georghiou and T. Saito (eds.), Pest resistance to pesticides. Plenum, New York.

Georghiou, G.P. 1986. The magnitude of the resistance problem. Pages 14-43 in E.H. Glass (ed.), Pesticide resistance: strategies and tactics for management. Nat. Acad. Sci., Washington, DC.

Georghiou, G.P. 1987. Insecticides and pest resistance: the consequences of abuse. Faculty Research Lecture, Academic Senate, University of California, Riverside, $27 \mathrm{pp}$.

Georghiou, G.P. 1990. Overview of insecticide resistance. Pages 18-41 in M.B. Green, H.M. LeBaron, and W.K. Moberg (eds.), Managing resistance to agrochemicals - from fundamental research to practical strategies. Am. Chem. Soc. Symp. Ser. 421, Washington, DC.

Georghiou, G.P., and A. Lagunes-Tejeda. 1991. The occurrence of resistance to pesticides in arthropods. Food Agric. Organ. U. N., Fiome. AGPP/MISC/91-1, 318 pp.

Georghiou, G.P., and C.E. Taylor. 1976. Pesticide resistance as an evolutionary phenomenon. Pages 759-785 in Proc. $X^{\text {th }}$ Int. Congr. Entomol. Washington, DC.

Georghiou, G.P., and C.E. Taylor. 1977a. Genetic and biological influences in the evolution of insecticide resistance. J. Econ. Entomol. 70: 319-323.

Georghiou, G.P., and C.E. Taylor. 1977b. Operational influences in the evolution of insecticide resistance. J. Econ. Entomol. 70: 653-658.

Georghiou, G.P., and C.E. Taylor. 1986. Factors influencing the evolution of resistance. Pages 157-169 in E.H. Glass (ed.), Pesticide resistance: strategies and tactics for management. Nat. Acad. Sci., Washington, DC.

Georghiou, G.P., A. Lagunes-Tejeda, and J.D. Baker. 1983. Effect of insecticide rotations on evolution of resistance. Pages 183-189 in J. Miyamoto and P.C. Kearney (eds.), 5th int. Congr. Pestic. Chem. (IUPAC), Kyoto. Pergamon Press, Oxford, U.K.

Gould, F., A. Martinez-Ramirez, A. Anderson, J. Ferré, F.J. Silva, and W.J. Moar. 1992. Broad-spectrum resistance to Bacillus thuringiensis toxins in Heliothis virescens. Proc. Nat. Acad. Sci. USA 89: 7986-7990.

Hemingway, J., C. Smith, K.G.I. Jayavvardena, and P.R.J. Herath. 1986. Field and laboratory detection of the altered acetylcholinesterase resistance genes which confer organophosphate and carbamate resistance in mosquitoes (Diptera: Culicidae). Bull. Entomol. Res. 76: $559-565$. 
Ketterman, A.J., K.G. I. Jayawardena, and J. Hemingway. 1992. Purification and characterization of a carboxylesterase involved in insecticide resistance from the mosquito Culex quinquefasciatus. Biochem. J. 287: 355-360.

Ketterman, A.J., S.H.P. Karunaratne, K.G.I. Jayawardena, and J. Hemingway. 1993. Qualitative differences between populations of Culex quinquefasciatus in both the esterases A2 and B2 which are involved in insecticide resistance. Pestic. Biochem. Physiol. 47: 142-148.

McGaughey, W.H., and M.E. Whalon. 1992. Managing insect resistance to Bacillus thuringiensis toxins. Science (Washington DC.) 258: 1451-1455.

McKenzie, C.L., and R.L. Byford. 1993. Continuous, alternating, and mixed insecticides affect development of resistance in the horn fly (Diptera: Muscidae). J. Econ. Entomol. 86: 1040-1048.

Mouchès, C., N. Pasteur, J.B. Bergé, O. Hyrien, M. Raymond, B.R. de Saint Vincent, M. de Silvestri, and G.P. Georghiou. 1986. Amplification of an esterase gene is responsible for insecticide resistance in a Culex mosquito from California. Science (Washington DC.) 233: 778-780.

Mouchès, C., Y. Pauplin, M. Agarwal, L. Lemieux, M. Herzog, M. Abadon, V. Beyssat-Arnaouty, O. Hyrien, B. Robert de Saint Vincent, G.P. Georghiou, and N. Pasteur. 1990. Characterization of amplification core and esterase B1 gene responsible for insecticide resistance in Culex. Proc. Nat. Acad. Sci. 87: 2574-2578.

Mullin, C.A., and J.G. Scott (eds.). 1992. Molecular mechanisms of insecticide resistance. Am. Chem. Soc. Symp. Ser. 505, Washington, DC. 322 pp.

Nielsen-Leroux, C., and J-F. Charles. 1993. Binding of Bacillus sphaericus binary toxin to a specific receptor on midgut brush-border membranes from mosquito larvae. Eur. J. Biochem. 210: 585-590.

Oei, C., J. Hindley, and C. Berry. 1992. Binding of purified Bacillus sphaericus binary toxin and its deletion derivatives to Culex quinquefasciatus gut: elucidation of functional binding domains. J. Gen. Microbiol. 138: 1515-1526.

Otto, D., and B. Weber (eds.). 1992. Insecticides: mechanisms of action and resistance. Intercept, Andover, England. 499 pp.

Pasteur, N., and G.P. Georghiou. 1989. Improved filter paper test for detecting and quantifying increased esterase activity in organophosphate-resistant mosquitoes (Diptera: Culicidae). J. Econ. Entomol. 82: 347-353.
Ranasinghe, L.E., and G.P. Georghiou. 1979. Comparative modification of insecticide resistance spectrum of Culex $p$. fatigans Wied. by selection with temephos and temephos/synergist combinations. Pestic. Sci. 10: 502-508.

Raymond, M., D. Fournier, J. Bergé, A. Cuany, J.M. Bride, and N. Pasteur. 1985. Single-mosquito test to determine genotypes with an acetylcholinesterase insensitive to inhibition by propoxur insecticide. J. Am. Mosq. Control Assoc. 1: 425427.

Raymond, M., V. Beyssat-Arnaouty, N. Sivasubramanian, C. Mouchès, G.P. Georghiou, and N. Pasteur. 1989. Amplification of various esterase B's responsible for organophosphate resistance in Culex mosquitoes. Biochem. Genet. 87: 417423.

Roush, R.T., and J.A. McKenzie. 1987 Ecological genetics of insecticide and acaricide resistance. Annu. Rev. Entomol. 32: 361-380.

Roush, R.T., and B.E. Tabashnik (eds.). 1990. Pesticide resistance in arthropods. Chapman and Hall, New York. 303 pp.

Soderlund, D.M., and J.R. Bloomquist. 1990. Molecular mechanisms of insecticide resistance. Pages 58-96 in R.T. Roush and B.E. Tabashnik (eds.), Pesticide resistance in arthropods. Chapman and Hall, New York.

Tabashnik, B.E. 1989. Managing resistance with multiple pesticide tactics: theory, evidence and recommendations. J. Econ. Entomol. 82: 1263-1269.

Taylor, M.F.J., D.G. Heckel, T.M. Brown, M.E. Kreitman, and B. Black. 1993. Linkage of pyrethroid insecticide resistance to a sodium channel locus in the tobacco budworm. Insect Biochem. Mol. Biol. 23: 763-775.

Thompson, M., F. Shotkoski, and R. ffrenchConstant. 1993. Cloning and sequencing of the cyclodiene resistance gene from the yellow fever mosquito Aedes aegypti. FEBS Letters 325: 187-190.

Van Rie, J:, W.H. McGaughey, D.E. Johnson, B.D. Barnett, and H. Van Mellaert. 1990. Mechanism of insect resistance to the microbial insecticide Bacillus thuringiensis. Science (Washington DC.) 247: 72-74.

Williamson, M.S., I. Denholm, C.A. Bell, and A.L. Devonshire. 1993. Knockdown resistance $(k d r)$ to DDT and pyrethroid insecticides maps to a sodium channel gene locus in the housefly (Musca domestica). Mol. \& Gen. Genet. 240: 1722. 